\title{
A TORRE DE ISMÁLIA: SOBRE MUROS INVISÍVEIS E SINGULARIDADES URBANAS
}

\author{
Ana Paula Vieceli ${ }^{1}$ \\ anavieceli@hotmail.com
}

\section{Resumo}

As linhas que se seguem tentarão exprimir a experiência de um acompanhamento terapêutico em suas errâncias por espaços da cidade de Porto Alegre, durante a participação no grupo ATnaRede da Universidade Federal do Rio Grande do Sul, em 2013. Entendendo a cidade como um lugar da loucura, um espaço de infinitas possibilidades de criação de modos existenciais para o louco, o tema da loucura e seus lugares se aproxima dos temas da cidade e do urbanismo e com estes vem somar-se. O AT, com sua capacidade de tecer redes de relações junto ao acompanhado, se ocupa também da experiência de construção de uma nova cidade. Acompanhante e acompanhado, acabam por se desprender das condições dadas de uma cidade para que uma outra cidade possa ser habitada. Essa nova cidade é construída no exato momento em que juntos, acompanhante e acompanhado, e demais atores que surgem no caminho, a percorrem. Essa construção se alinha com o devir polis da cidade, se alinha com o desejo de criação de uma cidade que possa acolher a diferença.

Palavras-chave: Loucura, cidade, polis, corpo

\begin{abstract}
The following lines will try to express the experience of a Therapeutic Accompaniment in their wanderings by spaces of Porto Alegre during the participation in ATnaRede group of the Universidade Federal do Rio Grande do Sul, in 2013. Understanding the city as a place of madness, a space of infinite possibilities of creating existential ways for the mad person, the theme of madness and their places approaches the city and urbanismo themes and it comes in its addition. The AT, with its ability to weave networks of relationships with the accompanied, also deals with the experience of building a new city. Companion and accompanied, eventually come of the given conditions of a city to another city that can be inhabited. This new city is built at the exact moment that together, companion and accompanied, and other actors that come your way, run along it. This construction aligns with the becoming polis of the city, aligns with the desire to create a city that can wellcome the difference.
\end{abstract}

Keywords: Madness, city, polis, body

\footnotetext{
${ }^{1}$ Arquiteta e Urbanista. Graduada pela Universidade do Vale do Rio dos Sinos - Unisinos (2011). Mestre pelo Programa de Pesquisa e Pós-Graduação em Arquitetura - PROPAR/UFRGS (2014), cuja dissertação "Lugares da Loucura: arquitetura e cidade no encontro com a diferença" recebeu o prêmio Enamparq de melhor dissertação (2015). Doutoranda pelo PROPAR/UFRGS e desenvolvendo a pesquisa sobre a cegueira e o invisível na arquitetura.
} 


\section{A TORRE DE ISMALIA}

Entrei no grupo ATnaRede ${ }^{2}$ levada por um desejo de aproximar-me da problematização da cidade como um lugar da loucura, sem no entanto saber exatamente o que me reservava essa peculiar trajetória. A princípio, num território estrangeiro, me supus como observadora dos acompanhantes em seus acompanhamentos narrados em supervisão. Num movimento inesperado, o próprio grupo me convocou a sair da posição passiva, inerte e neutra de mera observadora, para uma posição implicada, atuante e participante naquilo que o grupo se propunha: acompanhar sujeitos em sofrimento psíquico em seus processos de vida. Esquivei-me por um momento, na dúvida de mim mesma, por não entender que fosse possível para mim, arquiteta-urbanista, formação que parecia, na época, tão distante das disciplinas envolvidas em saúde mental, atuar como $a^{3}{ }^{3}$. Confiando na linha guia que já tinha me levado até ali, enchi o corpo de coragem para ir ao encontro do completo desconhecido, movimento este que, hoje percebo, esteve presente durante todo o meu percurso nos dois anos de mestrado e que se intensificaram vertiginosamente ao implicar meu próprio corpo na experiência do AT. Eis que, num dos encontros semanais com o grupo, já preparada para acolher um acompanhamento, surge o caso de Ismália ${ }^{4}$.

Ismália, senhora de seus quase 60 anos, diagnosticada com esquizofrenia paranoide, chegou até o projeto ATnaRede através de uma demanda advinda do Poder Judiciário do Rio Grande do Sul. Há quase um ano em Medida de Segurança ${ }^{5}$, Ismália foi encaminhada ao

\footnotetext{
${ }^{2}$ O Projeto ATnaRede, ligado ao Instituto de Psicologia da UFRGS desde 1998, opera como projeto de ensino, pesquisa e extensão em torno da prática do Acompanhamento Terapêutico (AT). Em parceria com serviços de assistência social, saúde e justiça do município, acolhe demandas oriundas desses serviços, com os quais mantém uma interlocução, no sentido de abrir espaço para discussão dos casos propostos para AT. O projeto é composto por estagiários de psicologia, residentes de saúde mental coletiva, extensionistas e mestrandos de diversas áreas do conhecimento. Conta com um espaço semanal de supervisão na universidade e prevê a participação em reuniões de rede e com as equipes dos serviços parceiros.

${ }^{3}$ Por convenção, utilizamos a abreviação AT para nos referirmos ao Acompanhamento Terapêutico, enquanto que at, em minúsculo, empregamos para designar a figura do acompanhante terapêutico.

${ }^{4}$ Nome fictício e poético que vem identificar, nesta narrativa, a acompanhada. O nome foi inspirado no poema de Alphonsus de Guimaraens cujos versos atravessaram este AT.

${ }^{5}$ A medida de segurança trata-se de uma forma de sanção penal, com caráter preventivo e curativo, visando evitar que o autor de um fato havido como infração penal, inimputável ou semi-imputável, mostrando periculosidade, torne a cometer outro injusto e receba tratamento adequado. A medida de segurança tem um prazo mínimo de um a três anos, porém o máximo da duração é indeterminado, perdurando a sua aplicação enquanto não for averiguada a cessação da periculosidade (Código Penal, artigo 97, parágrafo $1^{\circ}$ ).
} 
projeto ATnaRede para que pudessem ser ampliadas suas conexões com a vida citadina e para que retomasse o contato com a arte, objeto de sua formação e de seu interesse.

Até aqui sabia que Ismália havia adoecido mais ou menos cinco anos antes e, em decorrência disso, teria passado por dois momentos de internação em hospitais psiquiátricos privados. A segunda internação se fez via judicial devido a conflitos que surgiram entre ela e os moradores do condomínio onde morava e, desde então, cumpria a medida de segurança. Soube também que Ismália possuía uma rede de cuidados, em âmbito privado, muito ampla, à sua volta: família, cuidador, enfermeiras (mulher e filha do cuidador), psiquiatra e psicóloga, e que o AT viria, a princípio, para enriquecer as suas relações com a dinâmica da cidade relacionada com seu campo de atuação, as artes plásticas. Como arte e arquitetura são campos que possuem alguns entrecruzamentos e interfaces, e, como havia uma arquiteta no projeto ATnaRede, entendeu-se que poderia ser uma experiência interessante.

\section{CENA 1}

Para chegar até a casa onde Ismália morava, junto ao seu cuidador e à família deste, percorri a cidade de Porto Alegre em dois ônibus, num deslocamento de cinquenta minutos, no qual pouco a pouco foi-se me apresentando uma nova Porto Alegre, uma cidade desconhecida. Do espaço centralizado, de vias arteriais congestionadas e paisagens conhecidas, fui cada vez mais adentrando em paisagens inéditas, com sua gente, seu movimento, tantos mundos. Durante todo o caminho naquele dia de sol, me acompanharam pensamentos e sensações de curiosidade, um tanto de ansiedade e um pouco de medo e vazio no estômago. Pouco a pouco começaram a surgir verdes morros, o fluxo do trânsito foi ficando mais desobstruído, vias arteriais desembocaram em vias mais locais, estreitas, as alturas dos edifícios já eram mais baixas, o grão urbano, menor, algumas áreas, rarefeitas, e o verde, mais denso. Achei que tinha chegado ao meu destino, mas meu destino era me perder um pouco pelas ruas locais do bairro distante, pois havia tomado o ônibus errado. Caminhei por ruas compridas, sem passeio público, ladeadas por mato e de poucas edificações. Depois de uns vinte minutos cheguei num ponto nodal, referência visual para o desembarque em trajetos futuros, numa próxima vez, com o ônibus certo. Pedindo informação na farmácia, depois no bar, fui me aproximando cada vez mais do endereço escrito num pedaço de papel. A última indicação necessária foi: "sobe a ladeira, primeira à esquerda, primeira à direita." Achei. 
Conferindo o endereço, achei uma casa azul de dois pavimentos e jardim frontal, localizada num beco sem saída povoado por muitos cachorros e gatos. Esperei no portão, após tocar a campainha, e logo veio alguém me receber. Era a filha do cuidador de Ismália, que me encaminhou rapidamente para o interior da casa, acolhendo-me com um sorriso. Ismália já me esperava, recebeu-me com um abraço. Uma senhora de estatura baixa, cabelos claros e curtos amarrados na altura da nuca. Vestia-se de forma muito recatada e formal, a mesma formalidade com que se expressava, falando pausadamente num português corretíssimo. Sentamo-nos à mesa de madeira da cozinha e este foi o espaço construído em nosso primeiro contato, pois ali ficamos durante três horas, entre apresentações e diálogos sobre muito além do que apenas o contrato inicial do AT.

Confesso que não vi o tempo passar, me agradou muito poder, com Ismália, trocar ideias sobre arte e também sobre arquitetura, matéria de nosso interesse comum. Senti que muito poderia contribuir, mas principalmente muito teria a descobrir com Ismália. Ela tinha algo de muito cativante, um conhecimento sobre arte que me interessava profundamente. Entre uma fala e outra, às vezes se estabeleciam uns "brancos", assim chamados por Ismália para definir momentos em que ela esquecia o que dizia e perdia o fio da meada. Brinquei com ela dizendo que poderíamos utilizar esse quadro branco para desenhar sempre que surgisse a oportunidade. Ela riu comedidamente.

Ao falar sobre o que chamou de sua "condição", não pude deixar de perceber que Ismália tinha uma noção muito esclarecida, muito clínica, quase ensaiada, a respeito do seu diagnóstico, da sua experiência com as internações e a decorrente mudança de residência para o endereço de seu cuidador. Apresentou as profissionais psi que a acompanham, dizendo-se eternamente grata, sobretudo à psiquiatra que havia finalmente acertado o remédio para que pudesse se livrar do sofrimento dos seus sintomas alucinatórios auditivos. Ismália contou um pouco de sua paixão pela arte, mas relatou que após o período de internação não teve mais contato com seu material de desenho, interrompendo completamente sua produção artística. Nesse ponto da conversa a demanda pelo AT se confirmou, quando Ismália demonstrou grande interesse na lista dos lugares culturais que pude elencar para que pudéssemos escolher juntas a fim de realizar o acompanhamento. No entanto, ela demonstrou hesitação quando lhe falei que iriamos de ônibus, pois explicou que suas raras saídas de casa se davam sempre de carro, dirigido ou pelo cuidador, que reservava um dia da semana para levá-la ao mercado, ou pela psicóloga, para suas duas consultas semanais. Fora estas atividades, Ismália permanecia em casa, na companhia de sua televisão. 


\section{CENA 2}

Na semana seguinte, já estávamos lado a lado conversando enquanto a paisagem da cidade passava velozmente pela janela do lotação. Situação quase que (re)inaugural na vida de Ismália que não tomava qualquer condução coletiva havia tanto tempo, que nem ela mesma lembrava. O conforto do banco macio e do ar-condicionado surpreendeu até mesmo a mim, acostumada a fazer meus trajetos a pé ou de ônibus comum. Descemos numa parada, que, segundo o motorista, ficava o mais próximo do museu, nosso destino do dia, mas que, ainda assim, pedia uma boa caminhada até lá. Uma preocupação se instaura: a rótula do joelho doído da Ismália surge para mim inserida num contexto de outra rótula, tão doída para quem caminha quanto o joelho dela, mas uma rótula de fluxos urbanos, onde a paisagem parece ser feita de modo a esquecer o humano que caminha por ela. Esforçando seu joelho, Ismália enfrentou comigo a travessia difícil próxima à rótula viária: muitos carros, pouca calçada e, em certos trechos, quase nenhuma. Reduzi meus passos para dar passo ao passo da Ismália, que ofegava e culpava seu sedentarismo: "Me acomodei, Ana Paula, me acomodei...".

E assim, vagarosamente, ao som dos carros que passavam por nós, foi se abrindo, finalmente, uma nova paisagem feita de água e pedra: de um lado o rio, do outro, a arquitetura. Passamos lentamente pela frente do edifício de concreto branco, erguendo nossas cabeças e direcionando nosso olhar a contemplar a volumetria irregular, a expressividade dos braços que se separam do corpo principal do edifício, o contraste entre as linhas retas e as linhas curvas que completavam o desenho da tarde de céu azul e o vento fresco do outono.

Uma vez no interior daquele volume demos início, a pedido de Ismália, a um percurso espacial que começou lá em cima e foi descendo, escorregando pelas rampas sutilmente perfuradas de céu e paisagem. Não sabíamos quase nada sobre a exposição que nos aguardava, a não ser poucos dados sobre a origem do artista que expunha sua obra. Foi assim que entramos juntas no mundo monocromático do papel e do carvão, de onde inesperadamente jorrava um azul iluminado. $\mathrm{Na}$ sala de projeção, caixa escura de acesso labiríntico, uma animação nos prendeu a atenção. Eram imagens lindamente fortes acompanhadas por sons perturbadores, que me deixaram de início um tanto quanto insegura por Ismália. Alguns segundos depois, sentindo que ela estava compenetrada, absorta pelo filme em sua intensidade, decidi sustentar esse momento junto com ela. Ao final da projeção lembro de Ismália dizendo apenas: "Forte!", e depois, entre um intervalo e outro das obras que fomos vendo, comentava mais um pouquinho a respeitos das imagens que vimos lá: olhos, tripés, cafeteiras, ralos, gatos, vultos, todos elementos presentes na obra do artista. Em 
outra projeção Ismália se fixou a uma frase "Her absence filled the world", traduziu lentamente em voz alta e ficou em silêncio.

Seguindo a incursão pela obra de carvão, a cada passo dado surgiam novas imagens que, a mim, enchiam de afetos, os quais não sabia nem explicar, onde guardar nem para que usar. Com essa sensação de ter preenchido o vazio e o silêncio que se instaurava muitas vezes entre mim e Ismália, descemos juntas a sinuosa rampa, deslizando no espaço que afetava tanto quanto a obra exposta. No andar inferior encontramos o rinoceronte de jornal e arame que encantou Ismália pela sua simplicidade e fragilidade material que, por sua vez, davam vida a um animal forte e belo. Nos distraímos em meio a tantas esculturas, gravuras feitas sobre jornais e livros, o tom monocromático que fazia brotar palavras fortes escritas em tinta vermelha. Ismália parecia estar tão à vontade ao descermos a rampa seguinte, que deixava transparecer em seus olhos um brilho pela alegria de saber que nos aproximávamos do ponto que mais lhe interessava em nossa visita naquele dia: o acervo do artista pelo qual ela reservava uma enorme admiração. Esse foi o grande momento para Ismália que, com conhecimento e paixão, me explicava como uma professora tudo aquilo que eu ainda não sabia sobre esse artista e sua obra.

Foi Ismália quem convidou para o café, no volume destacado do conjunto arquitetônico. Sentamo-nos em frente à imensa janela de vidro para, em alguns momentos de silêncio, saborear um café amargo e ver o sol mergulhar na água do Guaíba. Ismália permaneceu pensativa. A luz do dia se foi de forma inesperada e Ismália preocupou-se em ir embora.

Dali onde estávamos não conseguimos pegar um lotação de volta, e táxi algum passava vago. Tivemos que caminhar mais um tanto em busca de táxi. Só fomos conseguir atravessar a avenida bem longe dali, e um sentimento de pedestre frustrado me abateu. Finalmente um táxi, que nos deixou, já noite, na frente da casa de Ismália, e, assim, nos despedimos. Dali eu teria ainda que retornar para minha casa, pegando um lotação e um ônibus, mas não antes de ser expulsa da rua de Ismália pelo cachorro, verdadeiro proprietário do território, que agarrou minha calça pelo calcanhar e me fez paralisar de medo antes de andar rápido sem olhar para trás. 


\section{CENA 3}

Na semana seguinte fui novamente buscar Ismália. No caminho, já quase conhecido, fui pensando de que maneira poderia fugir do cachorro dono da rua, mas não parecia ter jeito. Mudar o caminho até a casa de Ismália era impossível, já que se localizava em um rua sem saída, de um único acesso. Pensei em levar algum objeto para me defender, tamanho era o meu pavor do bicho, um cachorro amarelo e branco, de pelo curto e porte médio. Correr e gritar não pareciam ser soluções de enfrentamento com um cão. Estava já um pouco atrasada e Ismália, preocupada, me telefona. Avisei que estava quase chegando e, num impulso, pedi a ela que me encontrasse na parada, para que dali pudéssemos pegar o lotação até o centro sem que houvesse mais atraso, para que pudéssemos aproveitar nosso tempo juntas. Ela ficou pensando por um breve tempo e aceitou minha proposta. Desci do ônibus feliz por não ter que enfrentar meu medo, e caminhei em direção à parada onde combinamos. Passaram-se alguns minutos e nada de Ismália. A casa ficava a uns trezentos metros dali. Comecei a pensar que ela não viria. Mais alguns minutos e avisto Ismália se aproximando, sorridente, com uma pastinha na mão. Ela chega mais perto e me abraça, dizendo que nem lembrava a última vez que tinha saído do portão de casa sozinha. Perguntei como tinha sido a sensação, e ela respondeu sorrindo, num tom suspiroso: "Maravilhosa, maravilhosa...". Tomamos o lotação.

Ismália estava diferente nesse dia, falante, empolgada, disse que tinha começado a usar os lápis aquareláveis que eu lhe tinha emprestado e que tinha feito alguns croquis. A sua animação me contagiou completamente e falamos sem parar no trajeto até o centro. Depois de desembarcarmos no terminal, andamos por um curto trecho da Rua da Praia. Ismália disse que muito já havia frequentado essa rua e que tinha um carinho especial por ela. De fato é uma rua singular: longe dos carros, as pessoas caminham livremente, se cruzam, se esbarram, se encontram. É um lugar de pluralidade, de memória, de história e que concentra diversos equipamentos culturais da cidade. Sua paisagem vai mudando conforme o percurso e em uma de suas extremidades se dá o encontro com a orla do Guaíba.

Dessa vez estávamos prestes a adentrar uma espacialidade eclética, na qual predominam elementos neoclássicos, mas também art noveau e neobarroco-rococó. A sua arquitetura, antiga sede bancária, é um edifício sólido e robusto como uma caixa forte, de cantos arredondados, e fachadas de arenito rosa ornamentadas. Ismália e eu entramos no interior desse edifício dos anos trinta que reforça o tempo todo sua imponência com um pé direito de mais de doze metros de altura e com incidência de iluminação natural através de três grandes claraboias. Expostas estavam as pinturas, gravuras e desenhos de artistas 
expoentes do Modernismo brasileiro, e trechos de poemas do mesmo período. Nossa incursão por essas obras ocorreu da forma mais leve e agradável possível. Ismália estava se sentindo em casa junto às obras que lhe remetiam a um passado feliz de estudante e de artista plástica. Sempre falante, tecia comentários que mesclavam a arte, a arquitetura e a vida. A cada poesia que descobríamos exposta em áudio, ela vibrava e declamava os trechos de que se recordava. Fiquei surpresa com Ismália, que seguido apresentava muitos lapsos de memória, mas que, naquele dia em especial, mostrou sua "tela branca" cheia, e por demais colorida.

De obra em obra chegamos até um suporte onde estava escrito um trecho de uma poesia de Alphonsus de Guimaraens. Li em silêncio e percebi no poema a palavra “enlouqueceu”. Pensei: o que será que a Ismália vai achar?, sempre com aquele desconforto, o mesmo que tinha tido na semana anterior, de não saber se era capaz de sustentar a intensidade da arte e do enfrentamento com a palavra "loucura". E mais uma vez Ismália surpreende e tranquiliza minha aflição silenciosa. Ela já conhecia o poema e estava muito feliz por ele estar ali. Disse que o amava profundamente, achava-o uma história triste, mas que era lindo. Para confirmar a força desse momento eu quis ler para nós o trecho que estava exposto no suporte de acrílico branco:

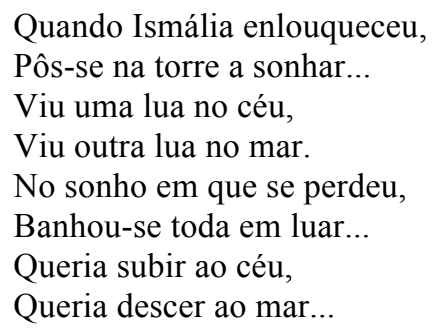

Sem dar tempo de uma pausa mais demorada, Ismália tomou a palavra e continuou recitando os trechos do poema que ela sabia de cor e que não estavam lá:

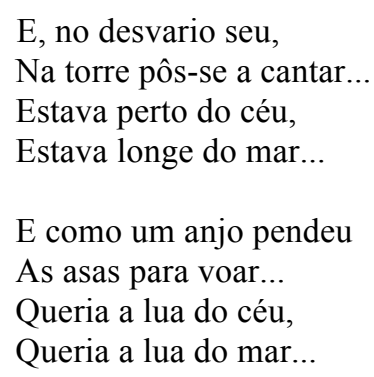

As asas que Deus lhe deu Ruflaram de par em par... Sua alma subiu ao céu, Seu corpo desceu ao mar... 
E assim que terminou de recitar, partiu em direção a outra obra. Eu não pude me mover. Fiquei ali, olhando para a poesia impressa em acrílico, sentindo algo totalmente estranho e grande me atravessar. Algo que até hoje não passou, e, se passou, deixou impresso, na minha própria "tela branca de acrílico", as palavras, sons e cores daquele instante.

Ao subir até o mezanino, encontramos uma exposição de uma beleza tão leve e tão rara. A artista expunha uma série de imagens fotográficas impressas em papéis artesanais, feitos por ela mesma. As imagens se mesclavam com a textura do papel fibroso, mas que possuía uma transparência leve, de uma materialidade tão delicada que parecia se desmanchar. As imagens eram poéticas e me remetiam a um sentimento doce e infantil. Ismália achou maravilhoso o trabalho da artista com o papel, e ficamos nos perguntando como tinha feito para imprimir imagens tão bem definidas em um papel tão frágil, que se desmancharia se o tocássemos. Junto à obra estava sendo projetada a imagem de uma grande bolha de sabão crescendo em câmera muito lenta, até que se estourava e se desfazia em micropartículas líquidas que iam sumindo, até que a bolha deixava de existir. O filme repetia o mesmo processo infinitamente. Pensei num dos grandes mistérios que me afligem desde a infância: o tempo que nunca para e que nunca volta. Pensei na transitoriedade das coisas e dos acontecimentos ao nosso redor, sendo afetados pela ação do tempo, nos momentos que nos passam tão rápido sem que dê tempo de percebê-los ou compreender o que nos acontece. E acabei me percebendo dentro de um momento transitório, cheio de cores e imagens, tempo compartilhado com Ismália e que, como a bolha de sabão, já se iria desfazer. Num misto de tristeza e alegria, dessa vez fui eu que convidei para o café.

Descemos até o subsolo, no cofre do antigo banco, e ali ficamos um tempo conversando sobre o que tínhamos visto e sentido naquela dia, tomando café, mas também falando muito sobre a experiência de Ismália no início daquela tarde, saindo sozinha de casa para vir ao meu encontro na parada de ônibus. Essa foi a grande questão da nossa conversa e meu questionamento era o que impedia esse movimento: medo, insegurança? Eu queria entender por que era tão difícil pra ela dar esse passo para a rua. Sem me dar resposta que clareasse a minha dúvida, ela falou sobre sentir que não podia sair.

Mas foi então que, depois de um breve silêncio, ela me perguntou como voltaríamos para casa naquele dia. Respondi que da mesma maneira viemos, com o mesmo lotação. Ela refez a pergunta: “Como você volta pra casa hoje, a partir daqui?". Eu perguntei: Daqui? 
daqui poderia inclusive voltar a pé. Então ela disse: "Vamos fazer assim hoje.”. Fiquei muito surpresa, ela disse que poderia voltar sozinha para sua casa, que pegaria o lotação, desceria na mesma parada onde nos encontramos e caminharia os trezentos metros a pé até sua casa. E assim ficou decidido. Estávamos as duas animadas com aquela ideia. Acompanhei Ismália até o lotação, no caminho ela ainda me disse que as exposições estavam the trazendo muita inspiração e vontade sobretudo de retomar seus desenhos. Me falou que mais tarde me mostraria seus antigos trabalhos e eu fiquei ansiosa por esse momento. Me despedi dela com um abraço, muito feliz por ela estar dando esse passo, a meu ver fundamental. Poder circular, descobrir mundos e se inspirar com a cidade e com o que a cidade oferece.

\section{CENA 4}

Se por um momento tive certeza de estar acompanhando um processo de movimento de Ismália na direção do mundo, no dia seguinte tudo ficou confuso.

Recebi uma ligação das profissionais psi que atendiam Ismália. Psicóloga e psiquiatra, numa ligação túrbida, realizaram um verdadeiro interrogatório, sem dar espaço para que eu pudesse entender o que se passava. Quem sou, o que sou, qual minha formação, qual instituição de ensino... queriam saber no que consistia exatamente o "experimento" que estava fazendo com Ismália, por quê, para quê, a pedido de quem. A cada tentativa de resposta eu era sacudida por novos questionamentos ou afirmações poderosas vindo de quem imaginei, por detrás daquela linha telefônica, trajar um jaleco branco. Antes que a ligação pudesse parecer mais absurda, insisti em saber os motivos da mesma, ao que a profissional respondeu não me poder revelá-los por razões éticas, mas que era para eu saber que tinha colocado a vida de Ismália em risco, e disse isso em um tom de voz alto antes de encerrar a ligação.

Mais tarde, soube que as profissionais psi que haviam me ligado exigiram o fim do AT, pois ele estaria contribuindo para uma desorganização de Ismália, bem como do ambiente estável em que ela se inseria, que levou muito tempo para ser ajustado, através de muitos acordos entre os profissionais envolvidos no cuidado de Ismália e a própria família desta. A exigência do fim do AT foi reforçada pela figura, para mim sempre oculta, da mãe de Ismália, uma senhora de seus quase oitenta anos, que morava longe de Porto Alegre e que administrava a distância a vida doente de Ismália, mantendo a sua curatela, delegando as funções aos vários profissionais em torno à sua filha, e que mantinha financeiramente este panorama de cuidado. Às profissionais psi, coube a tarefa dos cuidados medicamentosos, sua 
prescrição e observação para a estabilidade do seu quadro psíquico. Ao cuidador, que vim a conhecer mais tarde - um senhor simples, trabalhador da construção civil, de meia idade -, coube a responsabilidade de abrigar Ismália em sua casa e tomar conta das suas atividades cotidianas. $\mathrm{O}$ controle do banho, da alimentação e da medicação, era realizado em conjunto pelo cuidador, sua esposa e filha, estas que atuavam profissionalmente como enfermeiras. A circulação de Ismália se limitava a um dia da semana, no qual o cuidador tinha disponibilidade para levá-la de carro até o mercado. Além disso, Ismália possuía um espaço individual nesta casa, composto por um pequeno quarto no segundo pavimento e um banheiro. A internet não lhe era permitida, apenas a televisão.

De fato, Ismália estava inserida em um ambiente estável, constante dia após dia, que facilitava a economia e o cumprimento das tarefas e dos contratos realizados pela sua família. Neste cenário inerte, a presença do AT gerou a perturbação de uma dada ordem, quase intocável, cujas forças, a princípio, não se faziam visíveis. O movimento do AT, que para mim parecia ser tão sutil e, acredito, talvez até para Ismália, ameaçou violentamente a manutenção deste cercamento territorial seguro, controlado, asséptico e econômico em torno da doença mental de Ismália, diagnóstico que atestou sua reclusão em um mundo pobre de acontecimentos e vazio de esperança.

Mais de vinte anos passados desde a Reforma Psiquiátrica brasileira, desde que se anunciou o rompimento dos muros para os sujeitos portadores de sofrimento psíquico, ainda existem hoje muros tão sólidos e altos quanto os muros manicomiais. Muros que muitas vezes não podemos ver, mas que, ainda assim, estabelecem seu controle e sua força para capturar corpos e limitar vidas. Manicomial não pode ser o muro, objeto arquitetônico em sua dimensão física, mas uma sociedade que demanda espaço para o isolamento daquilo que considera indesejável, daquilo que não quer ver, daquilo que representa um desvio. Os muros materiais do manicômio não demarcavam apenas espaços físicos, mas expressavam um ideal de sociedade que, com a pretendida extinção dos muros físicos manicomiais, ainda continua a existir. Os muros invisíveis que demarcam o controle são instâncias simbólicas que ainda asseguram o funcionamento dos mecanismos autoritários e coercitivos manicomiais. No caso de Ismália, vemos enfim que ela, assim como no poema de Alphonsus de Guimaraens, estava sitiada em sua torre e rodeada de mar. Rodeada também de uma equipe composta por personagens que faziam ora papel de polícia, de médico, de enfermeiro, de administrador. Todos os personagens históricos do manicômio, quase que ao pé da letra, se repetindo mesmo fora dele. 
Meses depois da súbita interrupção do acompanhamento, encontrei Ismália. Um encontro marcado para concluir formalmente o AT. O cuidador estava junto. Trazia um discurso preparado, com todas as justificativas para que o AT não voltasse a ocorrer, afinal, a família de Ismália entendia que ela não tinha mais idade para certos passeios na cidade, não tinha sequer condições físicas para tanto. Também ressaltou os perigos que a rua representa, as vilas, os becos, os bandidos, o risco que é andar por aí... Ismália permaneceu quase o tempo todo em silêncio, mal tirava os olhos da grande janela de vidro. Parecia resignada e um tanto cansada. Na oportunidade que tive perguntei se estava tudo bem, se havia ficado com alguma má impressão do nosso percurso juntas, e ela respondeu "De maneira alguma, Ana Paula, mas é complicado. Eu preciso aceitar que minha condição é esta.”. No final, me devolveu os lápis aquareláveis e agradeceu. Disse que com eles havia produzido muito e que numa próxima oportunidade me mostraria seu trabalho. Esse momento nunca aconteceu.

E assim foi que Ismália voltou para sua torre a sonhar.

\section{OS LUGARES DA LOUCURA: DAS RUPTURAS COM O MANICÔMIO AO ESPAÇO DA CIDADE}

Talvez muitos o saibam: relacionar-se com a loucura sempre foi relacionar-se com a diferença. Antes de uma definição médico-científica é importante lembrar que aquilo que entendemos por loucura é, antes de mais nada, uma construção social, permeada por aspectos sociais, culturais e políticos, aspectos estes que foram se transformando ao longo das épocas. Essas transformações, por sua vez, nunca deixaram de imprimir seus reflexos expressando-se na materialidade do espaço construído, determinando os lugares da loucura na cidade, os espaços da diferença. Se colocarmos historicamente, lado a lado, loucura, arquitetura e cidade, ${ }^{6}$ podemos entender que a complexidade das maneiras como a loucura foi entendida e vivida em diversas épocas, resultou numa equivalente complexidade de lugares e arquiteturas dispostas na cidade, que acolheram desde o seu culto, sua celebração e ritos de cura, ao seu aprisionamento, até chegar por fim na sua captura pelo saber psiquiátrico o qual a transformou

\footnotetext{
${ }^{6}$ VIECELI, Ana Paula. Lugares da loucura: arquitetura e cidade no encontro com a diferença. 2014. 298 f. Dissertação (Mêstrado em Arquitetura). PROPAR-UFRGS. Porto Alegre, 2014.
} 
em objeto medico e através do hospital psiquiátrico propiciou a sua exclusão da paisagem da cidade ${ }^{7}$.

No entanto, é na contemporaneidade que se testemunha um processo de grande ruptura com o paradigma moderno manicomial: a Reforma Psiquiátrica é um marco das transformações que se deram nas formas de conceber a loucura e nas formas de cuidado e assistência ao louco. O movimento pela Reforma Psiquiátrica Brasileira possibilitou, através da progressiva extinção dos espaços manicomiais e da criação de uma série de equipamentos substitutivos ao manicômio, uma reconfiguração no cuidado em saúde mental para um espaço aberto, em liberdade, onde o tratamento se realiza na esfera comunitária e social. Os novos serviços, portanto, não se propõem como um novo modelo, mas sim com uma intenção de reconduzir o espaço de tratamento a uma abertura ao tempo e ao espaço.

Os lugares da loucura - tradicionalmente ligados à lógica moderna de exclusão, do fechamento total manicomial - se veem, assim, ampliados para fora deles mesmos. Desde a Reforma Psiquiátrica, o trabalho em saúde mental passa a incidir cada vez mais sobre um campo que é excêntrico ao hospital. Abandonam-se as grades, os muros altos, as paredes, o tempo sem cadência, os imensos pátios internos, os corredores extensos, este espaço que se autoexclui da paisagem da cidade, imóvel, completamente voltado para dentro de si mesmo, fechado entre muros e desabitado do tempo, como única forma possível ao louco. As novas formas de lidar com a loucura vão na direção de romper com muros da internação e da exclusão, inserindo-se cada vez mais no terreno vivo, múltiplo e cambiante da cidade, no contexto das trocas sociais que se estabelecem em comunidade. (PALOMBINI, 2004)

É preciso então considerar o meio urbano como lugar da loucura, pois é na cidade onde o louco retoma o seu direito fundamental: o convívio social, a produção de autonomia e de cidadania ativa. O cuidado em saúde mental passa a fazer parte do panorama da cidade apropriando-se dos bairros, das ruas, das praças, das igrejas, do bar da esquina, dos museus, enfim, dos espaços sociais: a cidade é seu novo território ${ }^{8}$.

7 A existência do louco atravessou grandes períodos históricos nos quais esteve em estado de liberdade, de aceitação comum e de coexistência no espaço comunitário; foi celebrada em rituais próprios, em procissões urbanas, no teatro grego; foi alvo de caridade religiosa, aceita em enfermarias, fossem elas claustrais e basilicais da Idade Média ou cruciformes do Renascimento, lugares comuns às pessoas doentes e necessitadas; passou por períodos de errância entre comunidades, navios, reclusão em prisões e torres; foi condenada, junto a todos os marginalizados, miseráveis e delinquentes aos hospitais gerais; e, enfim, encontrou-se com o território exclusivamente médico: o manicômio.

${ }^{8}$ Pensar o território se trata tanto de pensar um espaço concreto, definido pelas suas dimensões 
E é nesse contexto de deslocamento dos lugares de existência da loucura, da transposição dos espaços de clausura para o espaço comunitário, que surge o Acompanhamento Terapêutico ${ }^{9}$ (AT) como uma modalidade clínica. O AT é definido como uma clínica sem muros, que se desenvolve a céu aberto; Uma clínica nômade, que se realiza no espaço da cidade ou na direção dela, acompanhando sujeitos em seu cotidiano para favorecer os laços com o território onde habitam. Essa clínica se propõe como uma contribuição para a consolidação de um cuidado tomada dentro dos princípios que o movimento pela Reforma Psiquiátrica veio pautar. É muito interessante que o AT não é um campo de saber específico, e sim uma prática, portanto não se restringe a determinadas profissões ou especialismos, mas atravessa um conjunto de práticas para o qual convergem múltiplos saberes. Portanto, o exercício do AT não se limita ao campo psi $^{10}$, nem se restringe àqueles que detêm diploma de curso superior. Trabalhadores de diversas áreas de atuação, seja da esfera da saúde, das ciências humanas, das artes (e por quê não arquitetura e urbanismo?), e de diferentes níveis e formação, tem se dedicado ao AT como uma modalidade do seu fazer profissional e como campo de investigação e produção de conhecimento.

$\mathrm{O}$ at circula nas adjacências dos territórios, sejam eles da clínica de saúde mental, da família ou dos diversos territórios possíveis da cidade, ocupando os espaços vazios que existem entre eles (ROLNIK, 1997). O vazio aqui toma o sentido não de uma completa ausência, mas como de possibilidades. Como afirma Fuão (2008), assim como o movimento

mensuráveis, geográficas, arquitetônicas e urbanísticas, como também se trata de pensar um espaço existencial, onde se fazem e desfazem, se constroem e se derrubam, se reforçam ou se enfraquecem os laços sociais que dão sentido ao existir. O território onde acontece o cuidado, espaço que se abre e que amplia seus contornos, passa a estar cada vez mais relacionado a outros territórios socio-históricos e existenciais de trocas, de luta, de vida. (PALOMBINI, 2004)

${ }^{9}$ A prática do Acompanhamento Terapêutico surgiu nos anos sessenta nas comunidades terapêuticas na Argentina e no Brasil, e pode ser referida também às experiências de desinstitucionalização da loucura na Inglaterra, Estados Unidos e Itália. O AT tem sua gênese ainda no interior de instituições psiquiátricas privadas que conciliavam as formas de saber e poder próprias à psiquiatria tradicional, com algumas práticas inovadoras inspiradas na psiquiatria social inglesa, na antipsiquiatria e na psicanálise.

${ }^{10}$ No princípio dessa prática, o acompanhante terapêutico (at) - que na época chamava-se auxiliar psiquiátrico, amigo qualificado - tinha como tarefa apenas acompanhar o paciente, dentro da clínica ou, eventualmente, pela rua, e era visto como um agente cujo saber se encontrava à margem de uma formação técnica ou acadêmica, sendo subordinado ao saber psiquiátrico (A CASA, 1991). Contudo, a partir do momento em que emergem as críticas à estrutura social do hospital psiquiátrico tradicional, a figura do acompanhante desponta como um possibilitador de uma intervenção que buscar a simetria na relação com o paciente. É no horizonte da Reforma Psiquiátrica que o acompanhamento terapêutico ganha uma nova intensidade, inserindo-se como uma prática que se dá no campo das novas políticas de saúde mental, que, como vimos, propõe a desconstrução do modelo manicomial de assistência e cria novos equipamentos de saúde mental articulados entre si e com o território. Portanto, o espaço em que a experiência da loucura requer ser acompanhada não é mais o espaço do manicômio, mas sim o espaço da cidade (PALOMBINI, 2007). 
natural do cheio é esvaziar-se, o movimento natural do vazio só poderia ser encher-se. $\mathrm{O}$ vazio, esse lugar cheio de sentidos latentes, surge como uma potência de criação, e está sempre ali, aguardando que chegue o momento de encher-se e transbordar-se em acontecimento. "Todo vazio é um vir a ser, há algo de fascinante nesses espaços pelo que suscitam a imaginação." (FUÃO, 2008, s.p.). O vazio que o at, com seu acompanhado, vem habitar se transforma em um lugar do encontro, do encontro com a diferença, como o lugar propício ao evento, ao acontecimento, ao novo, ao impossível. É neste vazio entre os territórios já estabelecidos e aparentemente estáticos que o AT aparece como possibilitador da construção de modos de existência louca não doentes, não institucionalizados.

Do quarto para a casa, da casa para a calçada, para a rua, para o bairro, para a cidade: o at vai esticando linhas antes recolhidas num ponto só, vai possibilitando o cruzamento com novas linhas e a cidade, em sua condição favorecedora de acontecimentos, vai tratando de mudar suas direções, bifurcá-las, transmutá-las. A cidade, nesse sentido, divide com acompanhante e acompanhado papéis que se efetuam e muitas vezes se invertem no protagonismo dessa clínica itinerante. Mas que cidade é essa que o louco reencontra?

Pensemos nas cidades de hoje, já disciplinadas e esquadrinhadas pelo urbanismo moderno, pelos poderes disciplinares e de controle, onde há uma tendência de encapsulamento da vida para garantir uma certa invulnerabilidade, uma sensação de estar seguro: altos muros, grades, cercas elétricas, portões, portarias, porteiros, automóveis individuais, janelas fechadas, ruas expressas, estacionamentos protegidos. A cidade contemporânea foi conduzida na direção de transformar-se em uma cidade intocável, esvaziada, proibida aos sentidos humanos, atravessada por pessoas escondidas dentro de automóveis, separadas do contato da cidade pelo vidro, vivendo a cidade através de imagens, e cultivando o medo, altamente disseminado pelos meios de comunicação. É o medo o grande responsável pelo desejo desesperado de consumir os serviços de segurança, como se a segurança só pudesse, hoje em dia, ser conquistada pelo consumo. Ela se apresenta como produto, oferecido pelo mercado imobiliário, que aposta na vida condominizada, privatizada, composta por ilhas muradas dentro da cidade, pretendendo-se como uma mini-cidade afastada dos perigos da violência, da diferença, do estrangeiro. Como se não bastasse o zoneamento moderno, segregador do território da cidade, homogeneizador das relações sociais que se dão apenas entre os iguais, a cidade contemporânea, através de mecanismos sofisticados de controle, funda novos meios ainda mais sutis de segregação e exclusão, que contribuem para 
acentuar a desigualdade social e promover a violência simbólica e a violência real nas cidades.

Tendo o planejamento urbano se orientado pela pacificação, acabou por suprimir da cidade seus espaços de relação e, com isso, suprimiu-se também seu erotismo, a possibilidade de ligação e encontro com o outro. Dessa maneira, a força geratriz da cidade foi negada. Nega-se o encontro, as relações que brotam dele, as trocas - não só comerciais, mas principalmente trocas de olhares, de toques, de palavras, de ideias e de substâncias - e, no lugar disso, introduz-se meios que possibilitam o "contato à distância" enquanto se habita espaços artificiais e homogeneizados. Em decorrência disso, passa a ocorrer um esvaziamento dos espaços públicos e, aos poucos, a cidade passa a ter a sua vocação - de ser o lugar do convívio, da urbanidade, da civilização, da cultura, da esperança, da criação - relegada para um segundo plano, enquanto que é substituída por uma ideia de meio que possibilita a conquista do sustento, do "pão de cada dia", em decorrência do qual, se atinge um determinado modo de vida, muitas vezes sem vida. Dessa forma, a vocação da cidade se inverte: ao invés de produção de relações ela se torna em função das relações de produção. Essa simplificação da vida na cidade impossibilita percebê-la além da sua mineralidade: é a pedra sem o corpo. O que a cidade ganha em robustez material perde em fragilidade corporal, perde assim o seu próprio sentido. (BAPTISTA, 2010)

Mas apesar desse sintoma contemporâneo desolador, a cidade resiste! E é na qualidade de resistência que apresentamos o AT e trazemos a loucura para conversar com o urbanista e com o arquiteto: da mesma forma que o AT problematiza a desinstitucionalização da loucura como uma prática contínua (que não se finda com um conjunto de leis, ou com a extinção dos muros físicos do manicômio), também se coloca como um analisador do espaço urbano, onde esta prática se insere e onde se encarna ao percorrer seus mais variados caminhos.

A cidade, na sua dimensão de conjunto de relações, conflitos e negociação, isto é, como polis, é sempre criadora e mantenedora de fluxos diversos, e comporta a coexistência dinâmica de multiplicidades e de complexas redes de conexões de elementos heterogêneos em permanente transformação. É na dimensão da polis que emergem os Acontecimentos, as misturas, as zonas de vizinhança, contaminações, as diversas temporalidades. É com o sentido de polis que a cidade abre-se para o encontro e resiste à urbs, como única possibilidade de definição da cidade, isto é, forma, ordem, classificação, hierarquia, espaço matemático, espaço geométrico. 
Uma experiência da cidade que se instaura no corpo - corpo ordinário, corpo vivido, corpo cotidiano - é uma forma molecular (ou micro) de resistência aos processos molares (ou macro) de homogeneização tanto do corpo - corpo mercadoria, corpo imagem, corpo simulacro - como do corpo da cidade - corpo privatizado, corpo segregado, corpo gentrificado, corpo espetacularizado, corpo alienado etc. - uma vez que a cidade vivida e experienciada sobrevive à absorção pelos modos dominantes, no corpo daqueles que a experimentam. Os praticantes ordinários das cidades, aqui incluimos o movimento do louco, experimentam na carne os espaços quando os percorrem e os vivem e, assim, dão-lhe "corpo" pela simples ação de vivenciá-los. Através da apropriação, da experiência efetiva ou prática dos espaços urbanos, pela própria experiência corporal, sensorial, afetiva da cidade, os corpos denunciam, por sua simples presença e existência, a domesticação dos espaços espetacularizados, segregadores e esvaziados de sentido, assim como também revelam os aspectos vivos, pulsantes, acolhedores, que resistem aos processos desurbanizantes da cidade contemporânea. (BRITTO; JACQUES, 2008)

Na breve experiência junto à Ismália, pude perceber a importância do gesto do AT em criar e restituir laços, encadeamento de mundos, e sobretudo a importância que a cidade tem no desenvolvimento dessa prática. Foi de igual importância também perceber a persistência de certos muros. Esses muros são estruturas ou elementos arquitetônicos que, mesmo ao deixarem de existir fisicamente, continuam existindo no pensamento de uma sociedade que ainda carrega os vestígios, os rastros de muros manicomiais invisíveis. Muros que constituem uma herança do pensamento que entende a loucura como algo a esconder, a guardar entre muros, que desacredita no convívio e nas trocas com o mundo lá fora, que desautoriza a palavra do louco, excluindo da sua vida as possibilidades de construir novas dobras, novos modos de existir. Pensamento que entende a vida pulsante das cidades como um fator “desorganizador" e que pretende a simplificação de vidas em ambientes reclusos e empobrecedores, onde se leva em conta mais a economia da manutenção desse modo de vida do que a constante produção de outros modos possíveis onde os devires e os desejos possam ter lugar.

Recolocar os sujeitos que historicamente perderam as possibilidades de encadear o seu mundo ao mundo em funcionamento com a realidade urbana requer, de ambas as partes, louco e cidade, uma abertura para que esse reencontro possa acontecer, e com ele o resgate da loucura como um componente da cultura, que a própria sociedade tratou de ocultar por meio dos muros do manicômio e muros mentais invisíveis, que colocam um limite entre o eu-social 
e os a-sociais, entre os iguais e a diferença. Abrir a primeira brecha neste muro social invisível possibilita o gradual derruimento do mesmo, a partir do momento em que, pela brecha pequena, passam a entrar e sair fluxos os mais variados possíveis, sejam eles novos desejos, novas pessoas, novos lugares, novas situações.

O teor de novidade próprio ao AT como um dispositivo pode provocar sentimentos de estranhamento, medo, recusa, desconfiança, sentimentos que se instauram em um primeiro momento de contato com a diferença. Mas é preciso dar um primeiro passo na direção desse contato, pois o estranhamento se dá naquilo que desconhecemos, e desconhecemos por estarmos historicamente afastados da loucura e do seu saber-louco. Todo estigma só pode ser desconstruído no contato, nas bordas entre o eu e o outro.

A relação entre loucura e cidade se coloca como uma micropolítica de resistência ao apostar na cidade como polis, como o lugar das relações e dos conflitos, cujo espaço-tempo, tão predeterminado e orientado pela produção e pelo consumo, ao encontrar-se com os novos serviços de saúde mental e com a própria loucura, se vê atravessado pela diferença. É no espaço do comum que o louco vem buscar construir a sua reapropriação deste espaço ao mesmo tempo em que questiona os modos dominantes de se fazer cidade e põe à prova a capacidade da própria cidade em acolher a diferença, acolher o tempo do louco, o tempo do outro.

\section{REFERÊNCIAS BIBLIOGRÁFICAS}

A CASA, Equipe de acompanhantes terapêuticos do Hospital-dia (org). A rua como espaço clínico: acompanhamento terapêutico. São Paulo: Escuta, 1991.

BAPTISTA, Luís Antônio. Tartarugas e vira-latas em movimento: políticas da mobilidade na cidade. In: JACQUES, P. Berenstein; BRITTO, Fabiana Dultra (org.). CORPOCIDADE: debates, ações e articulações. Salvador: EDUFBA, 2010, p. 42-53

BRITTO, Fabiana Dultra. Co-implicações entre Corpo e Cidade: da sala de aula à plataforma de ações. In: BRITTO, Fabiana Dultra; JACQUES, Paola Berenstein (org.). Corpocidade: Debates, Ações e Articulações. Salvador: EDUFBA, 2010.

BRITTO, Fabiana Dultra; JACQUES, Paola Berenstein. Cenografias e corpografias urbanas: um diálogo sobre as relações entre corpo e cidade. Cadernos PPG-AU/UFBA, Vol. 7, edição especial - Paisagens do Corpo, 2008. p. 79-86. 
FUÃO, Fernando Freitas. Arquitetura e Vazio. Entrevista para Marina Mezzacappa. Julho de 2008. Disponível em: <http://fernandofuao.blogspot.com.br/2012/10/arquitetura-evazio.html>. Acesso em: out 2013.

PALOMBINI, Analice de Lima (Org.). Acompanhamento Terapêtico na Rede Pública: a Clínica em Movimento. Porto Alegre: Editora da UFRGS, 2004 . Vertigens de uma psicanálise a céu aberto: a cidade. Contribuições do acompanhamento terapêutico à clínica na reforma psiquiátrica (Tese). Doutorado em Saúde Coletiva. Universidade Estadual do Rio de Janeiro, Rio de Janeiro, 2007.

PALOMBINI, Analice de Lima; OLIVEIRA, Rafael Wolski de. Andanças: artes de habitar uma cidade. In: BAPTISTA, Luís Antônio (Org.); FERREIRA, Marcelo Santana (Org.). Por que a cidade?: escritos sobre experiência urbana e subjetividade. Niterói: Editora da UFF, 2012. p. 83-103.

ROLNIK, Suely. Clínica nômade. In: EQUIPE de Acompanhantes Terapêuticos do HospitalDia A Casa (Org.). Crise e cidade: acompanhamento terapêutico. São Paulo: EDUC, 1997, p.83-97.

VIECELI, Ana Paula. Lugares da loucura: arquitetura e cidade no encontro com a diferença. 2014. 298 f. Dissertação (Mestrado em Arquitetura). PROPAR-UFRGS. Porto Alegre, 2014. 